\title{
Investigate the Origin of the Components of Self-Determination Theory in Naturalism Thought
}

\author{
Farnaz Mehdipour Maralani (Corresponding author) \\ Master student of Educational Psychology, Faculty of Psychology and Education, \\ University of Tehran, Tehran, Iran
}

Afzal Sadat Hoseini

Associate professor of Educational science, Faculty of Psychology and Education, University of Tehran, Tehran, Iran

Received: March 21, 2016 Accepted: May 23, 2016 Published: May 24, 2016

doi: 10.5296/jsss.v3i2.9446 URL: http://dx.doi.org/10.5296/jsss.v3i2.9446

\begin{abstract}
The need for competence sense, autonomy and relatedness are the needs if are supplied have a significant impact in the individual's mental health. For a true understanding of the needs, the need to identifying is its thinking base. In this paper in the descriptive- analysis method, this intellectual infrastructure is proposed as naturalism and the origins and theoretical foundations self-determination on the basis of intellectual self-deploy, so it can be done if naturalism raising children are investigated on the basis of the infrastructure intellectual needs and as a result of it, if a child be educated by naturalism method can be effective on physiological and basis needs and as a result on self-determination of child. The naturalism doctrine can provide essential context to satisfy the basic psychological needs and thus self- determination. According to the doctrine of naturalism, intervention in nature must be appropriate to the stage of development that the child is at that stage, and it does not exceed, the intervention must be improved, not changer. Leave children to be free and the nature guide him the way he should go. Monitor his actions away. Give him tool feedback, not the executive one.
\end{abstract}

Keywords: Self-determination, Naturalism, Need, Competence, Autonomy, Communication

\section{Introduction}

People have natural and innate tendency to explore their environment that the intrinsic motivation plays an undeniable role in the growth trajectory (Soenens \& Vansteenkiste, 2010). 
Intrinsic motivation means doing an action for the activity because the person enjoys the process of work and elects the action for challenges and interest in it (Carreira, 2011). Over the years, various theories growth on motivation, including Self Determine Theory (SDT) and Deci and Ryan. A motivational theory that explains dynamic, motivational, emotional and well-being needs of human systematically in the essential and immediate context of the community (Chen \& Jang, 2010). This theory assumes that there is innate desire for learning and behavior in human that or encourages and guides by environment or weakens by neglect, (Deci \& Ryan, 2000). Ryan and Deci (2000), believe that perhaps no phenomenon reflects positive potential force of human nature as intrinsic motivation. Intrinsic motivation involves inherent tendency to seek novelty and challenges, to develop and practice individual capacity, exploration and learning. Experts of growth and development believe that children from the beginning of birth most healthy situation even in the absence of special bonuses, active, curious probe (like Harter, 1978, quoted Mousavi, 2014, p. 166). They believe intrinsic motivation structure of the natural tendency is toward internal- making, domination, intrinsic interest and exploration for basic and social cognitive development, and it is a major source of happiness and vitality throughout life (Ryan \& Deci, 2000). People experience intrinsic motivation due to have psychological needs. When doing an activity, psychological needs be active and foster, creates spontaneously a feeling of satisfaction in people. Intrinsic motivation is resulted from the feeling of competency and autonomous during doing an activity (Mousavi, 2014, p. 166). The main focus of self- determination theory on intrinsic motivation and addressing three basic needs (the need to feel competence, autonomy and relatedness) in humans (Janssen \&Vuuren, 2013).

\subsection{The Need for Competence}

Competence is a psychological need that provides intrinsic motivation to pursue optimal challenges and to make the necessary efforts to dominate them. When we doing a work that its difficulty level is fits exactly with our current skills, we feel we are very much interest to it and satisfies our need (Rio, 2006, quoted Mousavi, 2014, p. 160).

\subsection{The Need for Autonomy}

Need for self-compliance and having a sense of right of choice in the initiation is maintenance and tuning activities. Autonomy occurs when people feel that they are the cause of their behavior, that is, they have a sense of confident in their choices and are able to function optimally (Lavassani et al., 2011). Autonomy requires practice based on the will and having opportunity of the choice. For example, when persons are involved in an activity, do it completely voluntary. Because they find it interesting. On the contrary, the sense of control indicates the measures that are associated with a feeling of coercion or is done due to earn outer rewards. SDT theory founders believe that human behavior can be described in a continuum of autonomy and become control (Guay, Ratelle, Larose, vallerand, \& Vitaro).

\subsection{The Need for Communication}

When teachers and parents be held accountable and show that they are concerned about the interests and welfare of children, children show high internal motivation, but when interpersonal communication that children seek from adults is withhold, for example, when adults do not respond needs, children lose their intrinsic motivation (Volfok, 1998, cited 
Mousavi, 1993, p. 160). In addition, emotional and physical problems such as eating disorders and suicide is common more among people who lack social connections (according to the Volfok, 1998, quoted Mousavi, 2014, p. 160).

Self-determination is the need for choosing what we do and how we do it. People are trying to be responsible for their behavior. They fight permanently external pressures such rules, schedules, deadlines, common procedures and limits that others impose. Sometimes even people reject help others to keep their grip on matters. (Volfok, 1998, quoted Mousavi 2014, p. 160). According to self- determination theory, to know people's motivation it is necessary that their psychological needs for competence, autonomy and communication be addressed and ways to satisfy these needs be known. The first step is to satisfy the needs of the childhood. A child who feels being worthy, autonomy and supportive communication, his motivation increases and as a result becomes self- determination. Therefore it is necessary to know a context that have a major role to satisfy the children about these needs and child's selfdetermination. In this study, we aim to review this platform based on the naturalism thought foundation. In this doctrine that is represented by Rousseau, human personality must be organized in accordance with nature (Pakseresht, 2011, p. 96). We do not know how far nature will allow us to progress and none of us could measure distance between man and another (Rousseau, p. 73). If excessive and unnecessary interference becomes in the workings of nature, damages the individual's self-determination.

\section{Naturalism}

Naturalism is on the basis of the assumption that the nature is fundamental of reality. Nature is the overall system that encompasses and explains totality of being, including human and human nature. Rousseau as naturalism representative emphasized the importance of the individual's direct experience from natural environment. It should be trusted to the emotions that is product of personal touch of human with nature (Pakseresht, 2001, p. 96). The thing that nature should do within, if you act it out, have not done anything other than high risk (Emile, $\mathrm{p}$. 46). Before a child can get used to anything, they give him whatever he want without feeling threatened, but as soon as his force of perception becomes strong, all corrective actions may be dangerous for him. So to meet the future of child it should be tighten the care circle around him because we know that his future is at risk. So before he approaches danger shall be equipped to deal with potential risks (Emile, p. 47). An automatic training is a lot better than the kind of education that will be by force and coercion because when the children were automatic and they process their will, soon learn horse riding (Emile, p. 177). It may the best food be placed in front of him, but what is more delicious for him, is what he earns with hard work and struggle. As soon as the child could recognize things, let the child released to choose any of the objects. Everybody expects the kids beyond their ability (Emile, p. 214). He should not expect him to dictate your speech, his work is the effects of his opinion that originates from his desire (Emile, p. 215).

Rousseau proposed courageously the theory of naturalism launched a new design - but according to some it is a Copernican revolution in education. He offered human nature pure teachings. Pure and good people. Corruption exists of course, but it is an accidental issue that imposes the man from the outside from the community. Human not only has a clean nature, but also has the talent and the mechanisms of its development and perfection. Humans are 
inherently active, curious, good and growth potential. The role of training and education is not mastery of nature, but along with it. The role of education is not intervene in human nature, but also paving the way for its prosperity. Education should be in favor of nature. The Rousseau's aim is to train human development, natural human beings, the man regardless of the social hardness and perversity, the man who preserves its originality in the bosom of nature because of the training. Rousseau's theory offers modern human with a new nature and values (Pakseresht, 2007).

Could the intellectual infrastructure of naturalism in the training provide the necessary conditions to satisfy basic psychological needs and thus self-determination of the child?

An examination of the competence component of the theory of self-determination with a naturalism perspective:

Unfortunately, one of the issues that we face today is that nature is intervened a lot so that the person loses the ability to think. As a child want to access an object according to his natural desires and cannot and cries, to comfort ourselves, we easily give object to the child without realizing the fact that this cry is because of being disabled no because of the object is not available. Because this process, is a process that nature intends to enable. In the other word, first should there be a failure till the ability sense and feel worthy of being achieved. According to the theory of naturalism, if be taken much intervention in the natural growth of a person from childhood and be denied the right to freedom of children (do not allow children process under the natural growth). In fact, they will not experience a sense of competence because we do not allow give a worthy of being but also we give them worthy of being be that it will not be pleasant for them and their intrinsic motivation will decrease, this leads to dramatic consequences in the future, such as depression. If we want to examine why children are too much willing to play computer games from the perspective of this paper, we believe the causes is parents' high and improper interventions of the nature because the child want to experiences worthy of being based on his nature, while in the family environment he just has to run parents commands as a result he explores an environment where learns falling and getting up and thus experiences worthy of being and enjoys it and in this regard the computer game environment is the best choice for him!

\section{Emile and Sense of Competence}

If the child be lucky and happy absolutely, he becomes an authoritarian man, and thus his captivity will be inevitable and he will be the most miserable creatures. Your child should not get what he wants or he needs and you should not be entirely under his obedience unless in the necessity (Emile, p. 21), as if he would get everything, he does not try and feel real merit without effort is meaningless.

Allow the child to run and fall on the ground many a time that it is not an important issue. He learns over time to get up (Emile, p. 22) because if he learns getting up himself, his confidence increases and so gain a sense of competence. If humans was created large and powerful and his stature and physical strength is useless for him because of cannot use it and because he had become very arrogant so that deny assuming the help and the contribution of others. If this being had left before he could regain his requirements, death had end his life (Emile, p. 27). Because he would not place on the track of nature and could not never sense competence, 
because sense of competence is resulted from something that nature are gifted us, accordingly if we can use something that nature has marked out for us we get a sense of competence. Competence is not achieved never from what we have not and want to have compulsorily. When we are directed to different ways by nature on the one hand and by man on the other and if we be forced to divide ourselves into these two types of training we have come a common way that will not lead us to none of two sides (Emile, p. 35). Training is useful when parents can run it well and otherwise it is not beneficial for the child. So children should be trained that in a way that nature has given him steps firmly and at the end of the path be achieved to the being best of his way. Be simple but we work usefully, we don't cause to selfishness, it is not the honor that we turn away from what nature provided to us. This thought captures us (Emile, p. 276) guide your child in a way that nature has set for him, let your child perform the works that fit with his current skills to like them and the need for competence to be satisfied.

An examination of the communication component in the theory of self-determination with a naturalism perspective:

If you want a man to maintain its primary shape and structure, must be watched him from the day he is born. As soon as you walk in this world, handle him immediately as long as he becomes man do not turn away from him and otherwise you do not success (Rousseau, p. 49). Whatever social interaction be much and adults respond to their needs (namely the inopportune involvement in the process of nature, but children need to know that are important for adults and support them emotionally) children's intrinsic motivation become more.

Emile and the communication component in the theory of self-determination:

Man in this timeless valley is like a seedling that accidents grew in the desert and pedestrian removes him and whoever bends his back to destroy it (Emile, p. 27) so if the child has not good communication and the communications don't support him, the context of children's misery be provided gradually. Including those that have a key role in connection with the child is mother, as Rousseau in his book Emile wrote: Loving mother! I addressed to you, you should in this dusty desert keep and protect this small sapling from the clash of ideas (Emile, p. 27). When a mother instead of negligence in maternal duties overdo it and worship her child as an idol and to prevent the failure of her baby offered to him more food and keep him deliberately from any damage due to makes him out natural law, all these things are detrimentally for the child because he does not know how much the negative actions made him close to danger and how much to strengthen the weakness of the child by the maternal caress makes his disable and worn out against events (Emile, p. 46), thereby, it should be with children and help them in terms of intelligence and perception, or the power to overcome their shortcomings and the help and accompany should not exceed the physical requirements (Emile, p. 84). Our partnership with children should be limited in other things about the cooperation and help regardless unnecessary issues because child does not suffer so does not feel unreal and entertainment things (Emile, p. 84) we should talk with children and provide reason (Emile, p. 114). philosophize for your child, tell him whatever you want, yak and put to him against various questions. (Emile, p. 125) Is not bad that children be always supervised by a parent imprisoned in a room and don not let them to recognize the bad and good of life (Emile, p. 167) a social beings is a unit for community and he knows its value in assisting their affiliates (Emile, p. 32). 
An examination of autonomy component of the self-determination theory with a naturalism perspective:

When a man feel autonomy that knows himself responsible for his actions, according to Rousseau theory such a person if fall and we do not interfere in the process of nature, itself learns to get up and uses this experience to do not repeat wrong. Because he took responsibility for their actions, and regulate his behavior. According to self- determination theory it seems that intrinsic motivation is the product of two perception of self. People tend to be motivated internally in situations where sense competence and self- determination, (Ryan \& Deci, 2000, quoted Mousavi, 2014, p. 167). So if people found that at a certain situation can have successful performance (Bandura, 1998, Mousavi, 2014, p. 167) and can inhibit or regulate the situation significantly, more likely they are motivated internally to don't percept such or have incomplete perception. Social -tissue events (such as feedback, communications and reward) which leads to a sense of competence in their work can increase internal motivation for work. It is also indicated that optimized challenges and freedom from degrading evaluation all facilitate intrinsic motivation (Ryan \& Deci, 2000 quoted Mousavi, 2014, p. 168).

Emile and autonomy component in the theory of self-determination components:

One of the basic components of the theory of self-determination is autonomy that in Emile's book this is very important. Rousseau wanted to make a free man capable to defend against all tyranny, and be a human being fully free and unfettered (Emile, p. 20) dependency of things namely coincide with the needs of nature never damage children because a true freedom is certainly when a man obeys against the laws of nature. (Emile, p. 22) be careful them from afar and do not hurt their freedom and today all know that according to Emil method we should be observer of the freedom of children, from afar. (Emile, p. 25). If we leave the plant freely, we can make it curve by our energy, but its root has not lost the origin and nature and rises and if the plants begin to grow inevitably will resume its vertical stretches. (Emile, p. 29) Let the child as soon as he found his ability to understand emotions and to his liking can welcome to anything or avoid approaching his, that is, if he likes it, accepts it and otherwise draw it off and judge according to his understand and feel about it (Emile, p. 29). As soon as child could to recognize the things you release him to choose each of the objects (Emile, p. 75). He wants to touch everything, in the face of these concerns do not disagree with him, until gradually get used to it. (Emile, p. 77) any evil is the product of the inability, child is evil because feels himself unable, if make him strong, he becomes good and kind. A person who will do whatever he want, can never be bad, among all good attributes of God the goodness is the only point that if he had not has it was not strong (Emile, p. 82).

\section{Conclusions}

Being self- determination is one of the most important features that anyone should has to his psychological needs be provided. So it should be provided a context for individual's selfdetermination. In this article, self-determination theory and its components and also the view of naturalism and raising self-determiner children are examined. The first component of self-determination theory is the need to feel competence. Competence is a psychological needs that provides intrinsic motivation to pursue optimal challenges and to make the necessary efforts to dominate them. When children do something that its difficulty level fits exactly with his current skills, it feels very much interested and satisfies his need to competence. Let the 
child recognize worthy of being and earn it no give him. The second component is the need to autonomous. Autonomous is the need to self- compliance and having a sense of choice in the initiation, maintenance and tuning activities. Autonomy occurs when people feel that they are the cause of their behavior, that is, they have a sense of confident will in their choices and are enable to have optimal performance. Respect the freedom of our children and let him being autonomy and has passion, and monitor him from away. The third component is communication. When parents be held accountable and show that they are concerned about the interests and welfare of children, children show high internal motivation, but when children are withheld by interpersonal communication seeking form adults, for example, when adults are not responsive to their needs, children lose their intrinsic motivation, thereby our relationship with the child should be so that feel its worth. The child who has these features become a self-determination child, and his psychological needs about competence, autonomy and communication is provided.

By descriptive-analysis study in this paper, the naturalism doctrine can provide essential context to satisfy the basic psychological needs and thus self- determination. According to the doctrine of naturalism, intervention in nature must be appropriate to the stage of development that the child is at that stage, and it does not exceed, the intervention must be improved, not changer. Leave children to be free and the nature guide him the way he should go. Monitor his actions away. Give him tool feedback, not the executive one.

\section{References}

Akbari, R. (2003). Naturalism. Journal of Philosophy of Religion, 1, 89-106.

Goteg, G. L. (2005). Philosophical doctrines and educational ideas. Translated by Mohammad Jafar Pakseresht, Tehran, Samt publication.

Khwarizmi, A., Kareshki, H., \& Meshki, M. (2013). The role of basic psychological needs satisfaction and cognitive beliefs on students' intrinsic motivation of E- learning, 4, 17-9.

Lavassani, M., Khezri, Azar, H., Amani, J., \& Alizadeh, S. (2011). achievement: The role of the basic psychological needs and identification styles. Journal of education and learning, 1, 25-38.

Mousavi, S. M. (2004). Educational Psychology, Tehran, Savalan publication.

Pakseresht, M. J. (2007). Educational theory and theory challenges in Iran's education. Journal of Educational Innovations, 20, 125-146.

Rousseau, Jean-Jacques, Emile or Education, translated by A. Sobhani, Tehran, Farokhi Press Institute.

\section{Copyright Disclaimer}

Copyright for this article is retained by the author(s), with first publication rights granted to the journal.

This is an open-access article distributed under the terms and conditions of the Creative Commons Attribution license (http://creativecommons.org/licenses/by/3.0/). 